\title{
PEDAGóguSKéPZÉS A BEFOGAdó OKTATÁSÉRT EURÓPÁBAN
}

\author{
AMANDA WATKINS* - VERITY DONNELLY** \\ * az Európai Ügynökség a Sajátos Nevelési Igényü Tanulók Oktatásának Fejlesztéséért ${ }^{1}$ \\ munkatársa \\ amanda@european-agency.org \\ ** az Európai Ügynökség a Sajátos Nevelési Igényü Tanulók Oktatásának Fejlesztéséért \\ munkatársa \\ verity@european-agency.org
}

A tanulmány információkat tartalmaz az Európai Uniónak azokról az oktatási irányelveiröl, amelyek valamennyi európai pedagógus képzését érintik, foglalkozik az Európai Ügynökség a Sajátos Nevelési Igényü Tanulók Oktatásának Fejlesztéséért (az Ügynökség) projektjével, amelynek központi témája a „Pedagógusképzés a befogadó oktatásért” (TE41). Bemutatja a projekt célját, $s$ ennek kapcsán rávilágít az egyes országok elött álló lehetöségekre és kihívásokra, felhívja a figyelmet az Ügynökség TE41 projektjének részeként kialakitott befogadó tanári profil sajátosságaira.

\section{Bevezetés}

A pedagógusképzés kérdése Európa-szerte előkelő helyen szerepel a szakpolitikák napirendjén. Az Egyesült Nemzetek „A fogyatékossággal élö személyek jogairól szóló egyezménye" $(2006)^{2}$ egyre nagyobb lendületet és erőt ad a változtatásokhoz e területen. Az Egyezmény 24. cikkelye az oktatás számos szempontjára kitér, és hivatkozik az egyre növekvő számú kutatási eredményre azzal kapcsolatban, hogy a befogadó oktatás nemcsak a legjobb pedagógiai környezetet biztosítja a fogyatékkal élő tanulók számára, hanem segít ledönteni bizonyos korlátokat, és egyben megkérdőjelezi a kirekesztéssel veszélyeztetett tanulókkal kapcsolatos sztereotípiákat. Az elkülönített speciális oktatásra épülő iskolarendszerből egy befogadó rendszer felé vezető út fontos lépései közül az egyezmény kiemeli annak szükségességét, hogy a tanárképzés során minden leendő pedagógus kapjon felkészítést a befogadó környezetben való tanításhoz, és ahhoz is, hogy készek legyenek egymás támogatására. Ezt a következtetést sok más közlemény megerösíti nemzetközi és európai szinten is.

\footnotetext{
${ }^{1}$ The European Agency for Development in Special Needs Education

${ }^{2}$ A legfrissebb ratifikációs listát lásd: http://www.un.org/disabilities/
} 


\section{Oktatás és képzés Európa-szerte - a jelenlegi szakpolitikai környezet}

A „befogadás” kifejezést egyre több országban használják a kirekesztéssel fenyegetett tanulók jóval szélesebb körével kapcsolatban, mint amit a sajátos nevelési igényü tanulók jelentenek. A Nemzetközi Neveléstudományi Konferencia $\left(\mathrm{ICE}^{3}\right)$ 48. ülésén (2008) az a javaslat született, hogy a szakpolitikai döntéshozók ismerjék el a következőket: a befogadó oktatás egy folyamat, amelynek az a célja, hogy mindenki számára minőségi oktatást biztosítson, miközben tiszteletben tartja a diákok és közösségek sokszínüségét, eltérő igényeit és képességeit, tulajdonságait és tanulási elvárásait, felszámolva ezzel a diszkrimináció minden formáját. (Acedo et al., 2008).

Az Európai Unió különböző szerveiben az elmúlt években számos megegyezés, megállapodás született az oktatásról, amelyek befolyásolják a befogadó oktatást és ehhez kapcsolódóan a pedagógusképzést is. Emeljünk ki néhány meghatározó jelentőségü dokumentumot a stratégiai jellegüektől a pedagógusok és a vezetők szakmai fejlesztésével foglalkozókig.

2009 májusában az Oktatási Miniszterek Európai Tanácsa (European Council of Education Ministers) megállapodásra jutott az oktatás és képzés terén folytatott európai együttmüködés stratégiai keretrendszeréröl - ez az Oktatás és képzés 2020 (Education and Training 2020, ET 2020) munkaprogram. A dokumentum harmadik stratégiai célként a következőt fogalmazta meg: „Az oktatási és képzési rendszereknek arra kell törekedniük, hogy minden tanuló - beleértve a hátrányos helyzetü, a sajátos nevelési igényü és a migráns tanulókat is - befejezze tanulmányait, ha szükséges, második esélyt nyújtó oktatás és személyre szabottabb tanulás útján. Az oktatásnak támogatnia kell az interkulturális kompetenciák fejlesztését, a demokratikus értékeket és az alapvető jogok és a környezet tiszteletét, valamint harcolnia kell a diszkrimináció minden formája ellen, felkészítve ezzel minden fiatalt arra, hogy különböző hátterü társaikkal pozitív kapcsolatokat létesítsenek." (Council... 2009/a, 7. o.)

Az Európai Tanács legutóbbi következtetései az oktatás és képzés társadalmi dimenziója kapcsán felhívják a figyelmet arra, hogy az EU oktatási és képzési rendszereinek a kiválóságot és méltányosságot egyaránt biztositaniuk kell. Kiemelik, hogy az iskolai végzettség és a kulcskompetenciák általános javítása nemcsak a gazdasági növekedés és a versenyképesség szempontjából lényeges, hanem a szegénység csökkentéséhez és a társadalmi befogadáshoz is döntő fontosságú tényezők (Council of the European Union, 2010).

Az Európai Tanács 2007. november 15-i következtetéseiben a pedagógusképzés szinvonalának javitásáról az oktatásügyért felelős miniszterek egyebek között egyetértettek abban, hogy a pedagógusokat fel kell készíteni arra, hogy megfe-

\footnotetext{
${ }^{3}$ International Conference on Education
} 
leljenek az osztálytermekben tapasztalható, egyre fokozódó társadalmi és kulturális sokszínűség kihívásainak. Hangsúlyozták, hogy ez döntő fontosságú a méltányosabb oktatási rendszerek kialakításában, és a mindenkit megillető esélyegyenlőség előmozdításában (Council... 2007).

Végezetül az Európai Tanács következtetései a pedagógusok és iskolavezetők szakmai fejlesztéséről 2009-ben a következőt állítják: „fontos, hogy ne csak arról gondoskodjunk, hogy a tanári és iskolavezetői állásokra felvett jelentkezők a lehető legjobb képességüek és feladataik elvégzésére alkalmasak legyenek, hanem arról is, hogy a tanári állomány részére minden szinten biztosítsuk a legmagasabb színvonalú alapképzést és a folyamatos szakmai továbbképzést." (Council... 2009/b, 6. o.)

\section{Pedagógusképzés a sokrétű igények kielégítésére}

Jelenleg az európai szintủ szakpolitikai viták egyik kulcsfontosságú területe az, hogy a pedagógusokat miként készítik fel arra, hogy megfeleljenek az oktatásban egyre nagyobb mértékủ sokszínüség kihívásainak. A Bizottság közleménye a „Tanárképzés színvonalának javitásáról" (2007. augusztus 3.) tagállami szinten különböző szakpolitikai intézkedéseket sürget arra vonatkozóan, hogy a szakma a tudás alapú gazdaság új kihívásaihoz igazodva fejlődjön tovább. A közlemény a következőket mondja ki: „Az oktatásban és a társadalomban végbemenő változások új követelményeket támasztanak a pedagógus szakmával szemben. [...] az osztálytermekben most a különböző hátterü, különböző szintü képességekkel és fogyatékosságokkal bíró fiatalok sokkal heterogénebb elegyét találjuk. [...] Ezek a változások nemcsak új ismeretek és készségek elsajátítását követelik meg a tanároktól, hanem azok folyamatos fejlesztését is". (Commission..., 2007, 4. o.) A dokumentum kitér továbbá arra is, hogy a tanárok kulcsfontosságú szerepet játszanak abban, hogy felkészítsék a tanulókat arra, hogy elfoglalják helyüket a társadalomban és a munka világában. Rámutat arra is, hogy a tanároknak megfelelö készségekre van szükségük a következök kapcsán:

- az egyes tanulók sajátos igényeinek felismerése és válaszul a legkülönfélébb tanítási stratégiák alkalmazása;

- a fiatalok fejlődésének támogatása, hogy autonóm, egész életen át tanuló személyiséggé váljanak;

- a fiatalok hozzásegítése a Kulcskompetenciák Európai Referenciakeretében felsorolt kompetenciák megszerzéséhez;

- multikulturális környezetben végzett munka (ezen belül a sokféleség értékének megértése és a másság tiszteletben tartása);

- a munkatársakkal, a szülőkkel és a szélesebb közösséggel szoros együttmüködésben végzett munka. 
Mindezek mellett Az Európai Tanács 2007. november 15-i, a tanárképzés szinvonalának javitásáról szóló következtetéseiben (Council..., 2007) az oktatásügyért felelös miniszterek egyebek között kifejezték egyetértésüket a következőkkel:

- a tanároknak szaktárgyi tudásuk mellett pedagógiai készségekre is szükségük van;

- a pedagógusoknak képesnek kell lenniük arra, hogy a kompetencia alapú szemlélet alkalmazásával kulcskompetenciákat tanítsanak meg, hogy heterogén osztályokban is hatékonyan tanítsanak;

- szükséges, hogy a pedagógusok reflektív gyakorlatot és kutatást folytassanak;

- szükséges, hogy a tanárok egész pályájukon átívelő szakmai fejlödésük során maguk is autonóm tanulók legyenek.

A Tanács következtetései kiegészültek még néhány megállapítással. Megállapították, hogy a tanári alapképzés semmilyen formája nem képes felvértezni a leendő pedagógusokat az összes olyan kompetenciával, amelyre pályájuk során szükségük lesz. Kitértek arra is, hogy a tanári hivatással szemben támasztott követelmények gyorsan változnak, ami megköveteli a tanároktól, hogy saját iskolai környezetük összefüggésében mérlegeljék saját tanulási igényeiket, és hogy nagyobb felelősséget vállaljanak saját, egész életen át tartó tanulásukért.

\section{Pedagógusképzés a befogadó oktatásért - kutatási eredmények a közelmúlt szakirodalmából}

Ha áttekintjük egy sor európai ország tanárképzési programokkal foglalkozó szakirodalmát ${ }^{4}$, sok közös téma merül fel. Guðjónsdóttir és munkatársai (2008) hangsúlyozzák egy holisztikus megközelítés kialakításának szükségességét a befogadó oktatásban, a méltányosság, a szegénység és a sokféleség problémainak kezelése kapcsán. Saloviita (2005) egy közös terminológia és megfelelő inkluzív nyelvhasználat kialakításának fontosságát emeli ki, míg Esteve (2009) és Nuova (2009) azt mondja, hogy a „tanítás szakmai kultúrájához” kötődő ismeretek fejlesztésében a tanítási gyakorlat a kulcselem. Hajkova (2007) a reflexió fontosságát is hangsúlyozza a mélységelvü tanulásban.

A szakirodalom által tárgyalt egyéb fö témák között szerepel az elmélet és a gyakorlat közti szakadék áthidalásának (Mattson et al., 2006; Molina, 2006; Muñoz, 2009), valamint a kutatási készségek és „kutatói magatartás” kialakításának a szükségszerüsége (Rodrigues, 2009). Többen az olyan tulajdonságokat, mint a rugalmasság, a fogyatékossággal szemben mutatott pozitív magatartás és az eltérő

\footnotetext{
${ }^{4} \mathrm{http}: / /$ www.european-agency.org/agency-projects/teacher-education-for-inclusion/teacher-education-webfiles/TE4I-Lit-Review.pdf
} 
igényű tanulókban rejlő lehetőségekbe vetett hit, alapvető fontosságúnak tekintik (Tübele, 2008; Vandeputte et al., 2007). Sok más kutató rámutat arra, hogy fel kell számolni ,a tanulói tapasztalatokból fakadó korlátokat”, amelyek onnan erednek, hogy a tanárjelöltek maguk nem befogadó környezetben tanultak (Nakkarinen, 2008).

További szakirodalmi témák a kollégákkal és a tanulókkal fenntartott pozitív kapcsolatok biztosítására szolgáló készségek fejlesztése és a tanulók véleményének figyelembe vétele (Molina, 2006; Kaikkonen et al., 2007), a tanulás folyamatának ismerete (ezalatt a konstruktivista megközelítések ismeretét értik), a perszonalizációs és támogató stratégiák (Casonova et al., 2006; Kavklar, 2009; ONFRIH, 2008; Cefai et al., 2007), valamint a kutatás szükségessége és a tanárképzők közötti hálózatépítés fejlesztésének igénye (Franzkowiak, 2009). Mindezek mellett a szakirodalomban vitatéma, hogy miképpen lehet fejleszteni a fogyatékosság és a befogadás megértését a tanárképző intézményekben (Cardona, 2009).

Széles körben elfogadott nézet, hogy az együttmüködés a befogadó tanároknál alapvető fontosságú készség, de azoknál a speciális és hagyományos tanárképzési programokban dolgozó tanárképzőknél is kulcsfontosságú, akiknek különböző tartalmakat kell „összeolvasztaniuk” ahhoz, hogy jobban felkészíthessék a tanárokat az eltérő igények kielégítésére (Pugach és Blanton, 2009). Acedo és munkatársai (2008) azt a véleményt fejezik ki, hogy a szerteágazó nehézségekből fakadóan, amelyekkel valamennyi tanár szembetalálja magát, az egymástól függetlenül zajló képzési programok, amelyek egy része a speciális nevelési igényü, a többi pedig a fösodorba tartozó tanulók számára képez pedagógusokat, haszontalanok. Ezt a véleményt osztja Young is (2008), aki szerint a az ilyen rendszer által kitermelt képesítések és szakosodások egyre szélesedő skálája leszükíti azoknak a tanulóknak a körét, akiknek a tanítására a pedagógusok képesnek vélik magukat.

Összességében Hollins és Gunzman (2005) úgy véli, hogy a tanárképzés megköveteli az előítéletek visszaszorítását, egyfajta „méltányos pedagógia” kialakítását, valamint gyakorlati tapasztalatokat ahhoz, hogy a tanárok jobban megértsék a kulturális sokféleséget és érzékenyebbek is legyenek rá. A szakirodalom tehát támogatja azt az igényt, hogy a tanárképzés olyan irányba mozduljon el, amely minden tanárt felkészít a tanulók egyre sokrétübb igényeinek kielégítésére napjaink osztálytermeiben.

\section{Az Európai Ügynökség projektje: Pedagógusképzés a befogadó oktatásért (TE41 projekt)}

Az Európai Ügynökség a Sajátos Nevelési Igényü Tanulók Oktatásának Fejlesztéséért (az Ügynökség) 1996-ban jött létre a tagországok oktatási minisztereinek megállapodásával. Az Ügynökség minisztériumi képviselök állandó hálózata, amely a tagországok együttmüködési platformjaként szolgál - a társadalmi kohézió megteremtésének egyik eszközeként - az oktatás színvonalának és méltányosságának 
elősegítéséhez. Az Ügynökséget a tagországok (Ausztria, Belgium [flamand és francia nyelvü közösségek], Ciprus, a Cseh Köztársaság, Dánia, Egyesült Királyság [Anglia, Észak-Írország, Skócia és Wales]) Észtország, Finnország, Franciaország, Görögország, Hollandia, Írország, Izland, Lengyelország, Lettország, Litvánia, Luxemburg, Magyarország, Málta, Németország, Norvégia, Olaszország, Portugália, Spanyolország, Svájc, Svédország, Szlovénia tartják fenn, és az Európai Unió intézményei ${ }^{5}$ támogatják, bár ezektől az intézményektől függetlenül müködik.

Az európai szakpolitikai döntéshozók egyre fejlődő együttműködése a tanárképzés terén egy sor közös problémára és kiemelt területre világított rá a jövőbeli munka szempontjából. Ez az együttmüködés alapozta meg az Európai Ügynökség a Sajátos Nevelési Igényü Tanulók Oktatásának Fejlesztéséért a „Pedagógusképzés a befogadó oktatásért"elnevezésü projektjét. ${ }^{6}$. Az Ügynökség Képviselőtestületének tagjai és a Nemzeti Koordinátorok a következő kulcsfontosságú kihívásokat azonosították kiemelt kérdésként a projekten belül:

- Milyen tanárokra van szükségünk a befogadó társadalom megteremtéséhez egy XXI. századi iskolában?

- Milyen alapvető tanári kompetenciákra van szükség a befogadó oktatásban?

Megállapodás született arról, hogy a projekt a következökre fog összpontosítani:

- A tanárképzés fösodrában - tehát nem a speciális nevelési igényü tanulók tanítására felkészítő képzőintézményekben - képzett pedagógusjelöltek felkészítésének módjára a befogadó környezetben végzett munkára.

- Az alapképzésre mint prioritásra.

Alapvetően a következő kérdés átgondolására volt szükség: Az alapképzés során hogyan készitsünk fel minden pedagógust arra, hogy ,, befogadó” legyen?

Rendkívüli lehetőséget jelentett, hogy az Ügynökség tagországai között nagymértékủ az egyetértés a tanárképzés prioritásaival kapcsolatban, a közös problémák motiválóan hatnak az együttmüködésre szakpolitikai és gyakorlati szinten egyaránt. Ez az együttmüködő szemlélet adta az alapot az Ügynökség projektjéhez. A projekt 2009 elején indult, s az előkészületek után különböző tevékenységekre ágazott, amelyekben 25 európai ország 55 szakembere vett részt. Ezek a szakpolitikai és tanárképzői háttérrel rendelkező szakemberek közösen dolgoztak azon a kérdésen, hogy miként készítsék fel a leendő pedagógusokat a befogadó oktatásra a hagyományos, a fösodorhoz tantozó tanári alapképzésben.

\footnotetext{
${ }^{5}$ A 2007-2013 közti időszakra vonatkozó Jean Monnet cselekvési program az egész életen át tartó tanulás területén 2006. december 14-én lépett érvénybe: http://ec.europa.eu/education/programmes/llp/ structure/monnet_en.html

${ }^{6} \mathrm{http}: / /$ www.european-agency.org/agency-projects/teacher-education-for-inclusion
} 


\section{A projekt eredményei és ajánlásai}

A tanárképzés Európa-szerte további fejlesztést igényel, ha eredményesen kívánja felkészíteni a jelölteket az egyre sokfélébb tanulók igényeinek kielégítésére. A TE41 projekt eredményei megerősítik az európai szakpolitikai szinten kiemelt főbb problematikus kérdéseket, és egyértelmüen jelzik, hogy a fejlesztéshez a következökre lesz szükség:

- a pedagógusképzésbe jelentkezők hatékonyabb toborzására, és a megfelelő jelentkezők azonosítására eredményes kiválasztási folyamatokban;

- a tanárképzési rendszereknek, azon belül az alapképzésnek, a bevezetö szakasz (indukció) támogatási rendszerének, a mentorálásnak és a folyamatos szakmai fejlődésnek segítésére és színvonalának folyamatos emelésére;

- a szakma megerősítésére és a tanárképzők színvonalának biztosítására;

- az iskolavezetés fejlesztésére.

A projekt eredményeiből számos ajánlás született. Ezek egyrészt a tanárképzésben dolgozó szakembereket célozzák meg, másrészt azokat a szakpolitikai döntéshozókat, akiknek koherens szakpolitikai keretet kell teremteniük egy olyan széles körü, rendszerszintü változás kezeléséhez, amely a befogadó tanárok képzésének kialakításához szükséges. Nézzük meg az ajánlások lényeges elemeit rövid áttekintésben!

Toborzás és munkaerö-megtartás: szükség lenne a tanárjelöltek toborzását és a tanárok megtartását célzó hatékony módszerek kialakítására és annak felderítésére, hogy miként lehetne növelni a különbözö hátterü és fogyatékkal élö tanárok számát.

A tanárképzés eredményességének biztositása: a tanulók eltérő igényeinek kielégítését elősegítő tanári kompetencia minél hatékonyabb fejlesztése érdekében kutatásokra lenne szükség a tanári pályára vezető alternatív (a formális tanárképzéstől független) utak eredményességével kapcsolatban, valamint a formális tanárképzésben a képzés felépítésének, tartalmának és az alkalmazott pedagógiai, képzési módszereknek a hatékonyságáról.

A tanárképzők professzionalizációja: a tanárképzők „,szakmája” további fejlesztéseket igényel a toborzás, a bevezető támogatás és a folyamatos szakmai fejlődés terén. A felsőoktatásban dolgozó tanárképzők és a hasonló feladatokat ellátó iskolai személyzet elismertségét a megfelelő szaktudással és képesítéssel rendelkező jelöltek kinevezésével kell biztosítani. További feladat lenne egy formális bevezető (indukciós) szakasz kialakítása megfelelő támogatással, és annak kutatása, hogy miként lehetne biztosítani az állandó releváns osztálytermi tapasztalatszerzést a föiskolai, egyetemi képzők körében.

Együttmüködés az iskolák és felsőoktatási intézmények között: a tanárképzö programok fontos részét képező tanítási gyakorlatot az azt megalapozó elméleti 
kérdések világos megértésével kell megtámogatni, hogy a gyakorlat ne csak a legkönnyebben megfigyelhető és mérhető készségekre összpontosítson. Az iskoláknak és a tanárképző intézményeknek közösen kell dolgozniuk azon, hogy jó gyakorlóiskolai modelleket és megfelelő gyakorlótanítási lehetőségeket biztosítsanak.

Széles körü, rendszerszintü reform: a tanárképzés nem müködhet elszigetelten. A változás elősegítéséhez szükséges „teljes rendszerreform” elkötelezettséget és erős vezetést igényel a szakpolitikai döntéshozóktól minden szektorban, valamint az oktatásügy valamennyi érdekeltjétől. A munka során a szektorokon átívelő szakpolitikára, a különböző hatóságokat és hivatalokat felölelő gyakorlat fejlesztésére kell koncentrálni, hogy a befogadó oktatást mint az egyre befogadóbb társadalom kulcselemét támogassák.

A befogadás és sokféleség kapcsán alkalmazott nyelvi elemek tisztázása: a kategorizálás és a címkézés megerősíti az összehasonlításokat, hierarchiákat épít, korlátozhatja az elvárásokat és ennek eredményeként magát a tanulást is. A szakpolitikai reformnak minden tanárt és kulcsszerepet játszó szakembert segítenie kell az eltérő terminológia használatát alátámasztó előfeltételezések, illetve az eltérő terminológia használatából fakadó következmények jobb megértésében.

\section{A befogadó tanári profil kidolgozása}

Az Ügynökség országainak képviselői tájékoztatást kértek azokról a szükséges kompetenciákról, attitüdökről és normákról, amelyek a hagyományos, a fösodorhoz tartozó (többségi) iskolákban kialakított befogadó környezetben dolgozó tanároktól elvárhatók, illetve számukra szükségesek. Ez olyan alapvető kérdés, amelyet a tanárképzés prioritásaival foglalkozó nemzetközi dokumentumok és nyilatkozatok is kiemelnek. Ezért az Ügynökség egyik fö feladata az volt, hogy az oktatás fösodrában dolgozók számára kidolgozzon egy befogadó tanári profilt, amely a tagországoktól kapott információkra épül, de amely azután európai szinten is elfogadásra kerül. Az Ügynökség a befogadó tanári profil kidolgozása során hasznosította a projektben felhalmozott információtömeget. Ugyanakkor leginkább a projekt szakértőivel folytatott eszmecserékből merített, melyeknek célja azoknak a kompetenciáknak a felkutatása és megvitatása volt, amelyekre minden befogadó környezetben dolgozó tanárnak szüksége van a munkájához.

A hároméves időszak során a projekt tevékenységein belül számos olyan feladatot oldottak meg, amelyek a profildokumentum kialakításához füződtek. 2009 végén az Ügynökség munkatársai az országos projekt-szakértőkkel folytatandó megbeszélések ösztönzéséhez megfogalmaztak egy kezdő dokumentumot. A dokumentum számos alapvető kijelentést és gondolatot vázolt fel a befogadó tanárképzéshez szükséges tanári kompetenciák kapcsán, az alapját pedig a téma kutatásának és a szakpolitikai háttér-információknak az áttekintése adta. 2010-ben és 2011-ben 
egy sor tanulmányút ${ }^{7}$ szerepelt a tervekben különböző országokba. A 2010-es öt tanulmányút alatt sor került a profildokumentum vázlatának megvitatására, és az egyes országok vendéglátó csapata további konkrét kérdéseket vetett fel a kompetencia alapú szemléletek alkalmazása kapcsán. Az öt tanulmányút során folytatott tevékenységekben az országos projekt-szakértők mellett több mint 100 oktatásügyi szakember - ezen belül szakpolitikai döntéshozók, tanárképzők, diákok, iskolai dolgozók, specialisan képzett támogató szakemberek és közösségi csoportok képviselői - vett részt. A profildokumentum szükséges tartalmát érintő fontos gondolatok mellett az öt látogatásból fakadó kulcsfontosságú üzenetek a következők voltak:

- A kompetenciákat nem lehet egyfajta felsorolásnak tekinteni, amit sorra kipipálunk.

- Általában a neveléssel, konkrétabban pedig a befogadó oktatással szemben mutatott attitüdöknek és a mögöttük meghúzódó értékrendszernek van döntő szerepe, ezért ezekkel számolnia kell a tanárképzésnek.

A 2010-es országos tanulmányutak alapján egy átdolgozott és kibővített dokumentum került megvitatásra egy teljes projekttalálkozón Zürichben, 2010 öszén. Ez az átdolgozott dokumentum két dologban jelentősen különbözött az előző változattól. Elöször is azt a javaslatot tartalmazta, hogy a profil tartalma minden tanári munka kapcsán bizonyos alapvetö értékek köré épüljön (akkor hármat határoztak meg). Másodszor, elkülönült kompetenciák ismertetése helyett a dokumentum kompetenciaterületeket ajánlott, amelyek három elemböl állnak - attitüdök, ismeretek és készségek.

A fenti változtatásokkal valamennyi projekt-szakértő egyetértett. Ezek figyelembevételével és a szakértők által a dokumentum konkrét tartalmi részeire adott visszajelzései alapján elkészült egy átdolgozott profil. Ez a változat már négy alapvetö értékre épült, és minden egyes értéket sajátos kompetenciaterületek támasztottak alá. Ez az újabb vázlat adta az alapot egy sor „validációs” tevékenységhez 2011-ben a kilenc országot érintő tanulmányutak során. A projekt tevékenységein belül a validáció nem más, mint az érintettek széles körének megállapodása az értékek és kompetenciaterületek javasolt keretrendszeréről, valamint a profildokumentum konkrét tartalmáról. Minden látogatás alatt sor került számos eszmecserére az adott országba látogató projekt-szakértők és az ország tanárképzésben érintett felei között a profil kapcsán - annak tartalmáról és potenciális hasznáról. Ezek az eszmecserék messzemenően interaktívak voltak, fókuszcsoportok formájában zajlottak, ahol az érintetteket és a projekt-szakértőket arra biztatták, hogy visszajelzéseket adjanak, reflektáljanak.

\footnotetext{
${ }^{7}$ Az egyes országokban tett tanulmányutakkal kapcsolatos információk itt találhatók meg: http:// www.european-agency.org/agency-projects/teacher-education-for-inclusion
} 
A munka formái a kis csoportokban folytatott beszélgetésektől a nagy plenáris vitákig terjedtek, ahol több mint 50 érintett csoport képviselöi vettek részt. Az egyes országok projekt-szakértőin kívül a kilenc látogatás több mint 300 résztvevőt mozgatott meg. Ezek közé tartoztak:

- tanulók (sajátos nevelési igényekkel és azok nélkül), szüleik és családtagjaik;

- helyi közösségek képviselöi;

- osztályfőnökök, iskolavezetők, speciális nevelési igényű tanulók tanárai és a kisegítő személyzet;

- multidiszciplináris csapattagok (ezek között iskolapszichológusok, szociális munkások és egészségügyi szakemberek);

- $\quad$ tanfelügyelők, helyi területi oktatási vezetők, szakpolitikai döntéshozók;

- friss diplomás tanárok;

- diák-tanárok - tanárképzésben vagy továbbképzési programokban részt vevők;

- befogadó, sajátos nevelési igényủ és tantárgy alapú programokban dolgozó tanárképzők;

- tanárképző intézmények felsővezetői (rektorok, dékánok, tanszéki és kari vezetők);

- országos szintü szakpolitikai döntéshozók a befogadó oktatás és a tanárképzés területén.

A 2011-ben tett kilenc látogatást két információgyüjtési szakaszra bontották:

Információgyüjtés a validációhoz: a jóváhagyott sablon segítségével az első öt látogatás során visszajelzéseket gyüjtöttek a profillól, amelyeket azután a projektcsapat elemzett, hogy azonosítsa a látogatások során felmerült témákat és gondolatokat.

Információk megerősitése: az utolsó négy látogatás alkalmával a résztvevőknek bemutatták az első öt látogatás során felmerült fő irányzatokat és üzeneteket. A résztvevőket megkérték, hogy konkrét megjegyzéseket füzzenek a látogatások első szakaszában azonosított trendekhez, hogy ezzel megerősítsék vagy megkérdőjelezzék az eredményeket.

A kilenc látogatás során gyüjtött információk elemzése nyomán a következő megállapodások születtek:

- A profil alapvető kerete négy alapértékre és különböző kompetenciaterületekre épül.

- Valamennyi látogatás során elfogadták a profilvázlatban szereplő valamennyi kompetenciaterületet; vita fóleg arról folyt, hogy szükség van-e további kompetenciaterületekre.

- A profil bevezetésének lehetséges következményeit illetően egy sor probléma merült fel. Ezért a profil implementációját megvitató megbeszélés 
alapján javaslat született arról, hogy a profilvázlatban szereplö, a profil bevezetésére vonatkozó anyagot át kellene dolgozni egy külön résszé, amely csak a profil bevezetését segítő tényezőket tárgyalja.

A 2011-es találkozásokból nyert különbözö információk vezettek el a profil végső vázlatának elkészítéséhez. Ezt 2012 elején az Ügynökség összes képviselöjének és a kinevezett projekt-szakértőknek is elküldték véleményezésre. A végleges vázlatot a TE41 projekt disszeminációs konferenciáján is bemutatták, amelyre 2012 tavaszán Brüsszelben került sor. ${ }^{8}$

Az összes tevékenységből származó valamennyi visszajelzés, észrevétel és reflexió szolgáltatta az alapot a végleges profil és az azt alátámasztó anyag kidolgozásához, ami teljes egészében 21 nyelven elérhető lesz az Ügynökség honlapján 2012 végétől „,A befogadó tanár profilja” címü kiadványban.

\section{A befogadó oktatás értékekre alapuló megközelítése}

A befogadó oktatás egy átfogó koncepció, amely a köz- és a felsőoktatásban és a tanárképzésben különböző szakpolitikai lépéseket és megvalósítási módszereket igényel. A befogadó oktatás minden gyermeket és felnőttet érint; célja, hogy fokozza az egyének tartalmas részvételét a különbözö tanulási lehetőségekben és csökkentse kirekesztettségüket az oktatásból és tágabb értelemben a társadalomból.

A befogadó oktatás céljait olyan környezetben és rendszereken belül valósítja meg, amelyek mindenkit egyformán értékelnek, és amelyek az iskolákra mint a fenntarthatóságot elősegítő közösségi erőforrásokra tekintenek.

A befogadó oktatás elveken és jogokon alapuló megközelités, amelyet több központi érték támaszt alá: egyenlőség, részvétel, a közösségek fejlesztése és fenntartása, valamint a sokféleség tisztelete. A tanár által elfogadott értékek alapvetỏen meghatározzák a cselekedeteit.

Egyetértés volt a projekten dolgozók között abban, hogy a befogadó oktatáshoz elengedhetetlen tanári kompetenciák feltárásához szükséges kiindulópontnak ezeket az alapértékeket tekintik. Ezekre, a valamennyi tanuló tanításához és tanúlásához kapcsolódó alapértékekre épül minden pedagógus számára a befogadó oktatáshoz szükséges ismereteinek megszerzése, az ismeretek megértésének elmélyítése és a gyakorlati megvalósításhoz szükséges készségeinek fejlesztése.

\footnotetext{
${ }^{8}$ A konferenciával kapcsolatos információk itt találhatók: http://www.european-agency.org/agencyprojects/teacher-education-for-inclusion
} 


\section{Modell a befogadó tanár profiljához}

A kompetenciaterületek leírása a befogadó oktatásban tevékenykedő valamennyi tanár számára alapvető fontosságúnak tartott alapértékekre épült. Ezek az alapértékek:

- olyan elvek, amelyeket a tanárok tettei is tükröznek;

- „elmélettel gazdagított gyakorlati tudássá” válnak a tanárképző kurzusokon zajló tanulás során;

- az értékek gyakorlatban történő megjelenését demonstrálják a kompetenciaterületek részei, az attitüdök, a készségek és az ismeretek.

A kompetenciaterületek leírása a befogadó oktatásban tevékenykedő valamennyi tanár számára alapvető fontosságúnak tartott alapértékekre épül. A kompetenciaterületek három elemből tevődnek össze: attitüdök, ismeretek és készségek. Egy bizonyos attitüd vagy meggyőződés megkövetel bizonyos ismereteket vagy a megértésnek egy bizonyos szintjét, majd pedig készségeket ahhoz, hogy ez a tudás gyakorlati helyzetben is alkalmazható legyen.

Négy olyan alapértéket sikerült azonosítani, amelyek minden befogadó oktatásban tevékenykedö tanár számára döntő fontosságúak. Ezek szolgáltatják az alapot az összes tanár számára szükséges kompetenciaterületek leírásához. A négy alapértékhez kötödö kompetenciaterületek a következök:

- A tanulók sokféleségének megbecsülése - a tanulók különbözősége az oktatás egyik erőforrásának és tőkéjének tekintendő

- Elképzelések a befogadó oktatásról.

- A tanár véleménye a tanulók különbözőségéről.

- Valamennyi tanuló támogatása - a tanároknak minden tanuló eredményeivel kapcsolatban nagy elvárásai vannak

- Hatékony tanítási megközelítések heterogén osztályokban.

- Minden tanuló tanulmányi előrehaladásának és társadalmi beilleszkedésének elősegítése.

- Közös munka másokkal - az együttmüködés és a csapatmunka minden tanár számára alapvető fontosságú megközelítést jelent, így kiemelten fontos a

- $\quad$ szülőkkel és családokkal közösen végzett munka;

- más oktatásügyi szakemberrel együtt végzett munka.

- A személyes folytonos szakmai fejlődés fontossága - a tanítás egyben tanulási folyamat is; a tanároknak felelősséget kell vállalniuk saját, egész életen át tartó tanulásukért

- A tanárok mint reflektív gyakorló szakemberek.

- A tanárképzés mint a folyamatos szakmai tanulás és fejlődés alapja. 


\section{Záró megjegyzések - a profildokumentum használata}

2010 öszén a zürichi projekttalálkozón tartott programbeszédében Tony Booth professzor a következőket mondta: „A hatalom, amellyel mi oktatókként rendelkezünk az, hogy párbeszédbe vonjunk be másokat - ez minden.” Ez a kijelentés összegzi a profildokumentum szándékait - bevonni másokat az eszmecserébe.

A profildokumentum nem végsö dokumentum, végsö produktum, ami valamilyen módon „átültethető” egyes országok körülményei közé. A célja csupán az, hogy további eszmecserére ösztönözzön, előmozdítsa a döntéshozók és gyakorló szakemberek gondolkodását.

A dokumentum a befogadó tanárképzésnek sok olyan aspektusát emeli ki, amelyek további vizsgálatot igényelnek:

- Van egy fejlődő, de még mindig eléggé szük körü, korlátozott érvényü kutatási alap, amely dokumentálja, hogyan zajlik - vagy kéne zajlania Európa-szerte a befogadó környezetben tanító tanárok felkészítése.

- Sok országban folyik vita a tanárképzés felépítéséről, valamint arról, hogy hol és milyen keretek között kellene történnie (egyetemeken és/vagy iskolákban), és kik legyenek tanárképzők.

- A tanárképzési programok felépítését és tartalmát is sok országban vitatják, illetve felülvizsgálják.

Összegezve, országos és nemzetközi szinten egyaránt folyik a vita arról, hogy mit is jelent a hatékonyság a tanárképzésben. Ám mindenki azt reméli, hogy a „Befogadó tanár profilja" hozzájárul majd a szükséges eszmecserékhez, és alkalmas lesz a viták és kutatások előmozdítására országos és európai szinten egyaránt.

A befogadó oktatáshoz szükséges kompetenciák kiindulópontjai olyan, a tanításhoz és a tanuláshoz kötődő alapvető nézetek, meggyőződések és értékek lehetnek, amelyek alapot adnak a tudás megszerzéséhez, a jobb megértéshez és a készségek gyakorlati hasznosításához. Ezek az alapvető értékek minden tanár munkáját érintik, ám a befogadó oktatás kapcsán számos olyan sajátos kompetenciaterület (inkább kompetenciaterület mint sajátos, elkülönült kompetencia) létezik, amelyeket minden tanárnak fejlesztenie kell ahhoz, hogy munkáját eredményesen tudja végezni befogadó osztályokban is.

További információkért a „Pedagógusképzés a befogadó oktatásért” projekt vagy az „Európai Ügynökség a Sajátos Nevelési Igényü Tanulók Oktatásának Fejlesztéséért" munkája kapcsán kérjük, forduljon Amanda Watkins-hoz:

amanda@european-agency.org 


\section{Irodalom}

Acedo, C., Amadio, M., Opertti, R. with Brady, J., Duncombe, L., Weyermann, M., Huang, Y., Xu, X. (2008, Eds): Defining an Inclusive Education Agenda: Reflections around the 48th session of the International Conference on Education. UNESCO IBE, Genova.

Cardona, C. M. (2009): Teacher Education Students' Beliefs of Inclusion and Perceived Competence to Teach Students with Disabilities in Spain. Journal of the International Association of Special Education, 10(1) 33-41.

Casonova, R., Charentin, P., Cosnard, B., Croisy, J. P., Jollec, M. P., Rault, C. (2006): French beginning teachers confront special educational needs in some of their pupils. In: Gash, H. (ed.): Beginning teachers and diversity in school: A European Study. Instituto Politécnico de Bragança Report of research undertaken within Comenius Project 94158-CP-1-2001-FR.

Cefai, C., Fenech, L., Galea, E. (2007): Initial teacher education for individual educational needs: Newly qualified Maltese teachers' views. In: Bartolo, P. A. et al. (Eds): Responding to student diversity: Teacher Education and classroom practice. University of Malta, Malta.

Commission of the European Communities (2007): Communication from the Commission to the Council and the European Parliament: Improving the Quality of Teacher Education 3/08/2007 http://ec.europa.eu/education/com392_en.pdf

Commission of the European Communities (2008): Communication from the Commission to the European Parliament, the Council, the European Economic and Social Committee and the Committee of Regions Brussels 3.7.2008 Improving competencies for the $21^{\text {st }}$ Century: An agenda for European Cooperation in schools. http://eur-lex.europa.eu/ LexUriServ/LexUriServ.do?uri=COM:2008:0425:FIN:EN:PDF

Commission of the European Union (2008): Communication from the Commission to the European Parliament, the Council, the European Economic and Social Committee and the Committee of the Regions: An updated strategic framework for European cooperation in education and training, Brussels 16. 12. 2008 Link: http://ec.europa.eu/education/ lifelong-learning-policy/doc/com865_en.pdf

Council of the European Union (2007) Conclusions of the Council and of the Representatives of the Governments of the Member States, meeting within the Council of 15 November 2007, on improving the quality of teacher education. http://eur-lex.europa.eu/LexUri Serv/LexUriServ.do?uri=OJ:C:2007:300:0006:0009:EN:PDF

Council of the European Union (2009/a): Council conclusions on a strategic framework for European cooperation in education and training ('ET 2020') (12 May 2009) http:// eurlex.europa.eu/LexUriServ/LexUriServ.do?uri=OJ:C:2009:119:0002:0010:EN:PDF

Council of the European Union (2009/b): Council conclusions on the professional development of teachers and school leaders Brussels, 6 November 2009 Link: http://eur-lex. europa. eu/LexUriServ/LexUriServ.do?uri=OJ:C:2009:302:0006:0009:EN:PDF

Council of the European Union (2010) Council conclusions on the social dimension of education and training. $3013^{\text {th }}$ Education, Youth and Culture meeting, Brussels, $11^{\text {th }}$ May 
2010 http://www.european-agency.org/news/news-files/Council-Conclusions-May2010-Social-Dimension.pdf

Esteve, J. M. (2009): La formacion de profesores; bases teoricas para el desarrollo de programas de formacion inicial [Teacher training. Theoretical basis for the development of preservice training programs] Revista de Educacion, 350 Septiembre-Diciembre, 15-29.

Franzkowiak, T. (2009): Integration, Inklusion, Gemeinsamer Unterricht - Themen für die Grundschullehramtsausbildung an Hochschulen in Deutschland? Eine Bestandsaufnahme. [Integration, inclusion, inclusive education - topics of primary school teacher training at universities in Germany? A Survey] Bidok Digitale Volltextbibliothek, Available online at: http://bidok.uibk.ac.at/library/franzkowiak-integration.html Last accessed 21/03/10

Guðjónsdóttir, H., Cacciattolo, M. Dakich, E., Davies, A., Kelly, C., Dalmau, M. C. (2008): Transformative Pathways: Inclusive Pedagogies. Teacher Education in Journal of Research on Technology in Education Winter 2007-2008, Vol. 40, Number 2. 165-182.

Hajkova, V. (2007): Nová profesionalita pedagogů v inkluzivní školní praxi. In: Šimoník, O., Škrabánková, J., Št’áva, J. (eds.) Dimenze pedagogické práce s nadanými žáky. Sborník referátů z mezinárodního semináře [CD-ROM]. Brno: MSD, spol. s.r.o. 94-103.

Hollins, E. R., Gunzman, M. T. (2005): Research on preparing teachers for diverse populations. In: Cochran-Smith, M., Zeichner, K. M. (Eds): Studying Teacher Education. Mahwah, N. J. Lawrence Erlbaum Associates, 477-548.

Kaikkonen, L., Maunonen-Eskelinen, I., Aidukiene, T. (2007): Supporting Teachers' Competences towards the Development of a More Inclusive School - Listening to the Voices of Students with Special Educational Needs in Educational Transitions. Latvijas Universitātes Raksti. 2007, 715, 132-144.

http://pdc.ceu.hu/archive/00005366/ 01/715.pdf\#page=132 Letöltve: 22/03/10

Kavkler, M. (2009): Vloga pri uresničevanju inkluzije [The teacher's role in inclusion] Vzgoja in izobraževanje, letnik 40 št.5-6, 2009, str. 6-11.

Mattson, M., Dage Ore, H., Pisila, S. (2006): Vad är värdefull specialpedagogisk kunskap? [What knowledge is of value in Special Education?] Lärarhögsk, Stockholm.

Molina, S. (2006): Teacher education students' and first year in-service teachers' perceptions about their initial educatioon in relation to the special educational needs of Spanish pupils. In: Gash, H. (Ed): Beginning teachers and diversity in school: A European Study (Instituto Politécnico de Bragança). Report of research undertaken within Comenius Project 94158-CP-1-2001-FR)

Muñoz, E. (2009): La formacion del profesorado de Educacion Secundaria: contenidos y aprendizajes docents [Secondary Education Teacher Training; teaching content and teacher's learning] Revista de Educacion, 350 Septiembre-Diciembre 79-103.

Nakkarinen, A. (2008): Developing inclusive primary school teacher education: Experiences of Department of Teacher Education at the University of Jyväskylä, Finland. Paper presented at: Cross-National Invitational Symposium on Teacher Education for Inclusion, University of Aberdeen, 2-4 November 2008. 
Nuova, A. (2009): Para una formacion de profesores consruida dentro de la profesion [Towards a teacher training developed insider the profession] Revista de Educacion, 350, Septiembre-Diciembre, 203-218.

ONFRIH (2008): Observatoire national sur la formation, la recherche, et l'innovation sur le handicap [National observatory for training, research and innovation upon disability report]. http://www.travailsolidarite.gouv.fr/IMG/pdf/Rapport_ONFRIH_2008.pdf Letöltve: 2010. 03. 20

Pugach, M., Blanton, L. (2009): A framework for conducting research on collaborative teacher education. Teaching and Teacher Education, 25(4) 575-582.

Rodrigues, D. (2009): Inclusion and Teacher's Education: who reforms the reformers? Cross-National Invitational Symposium Teacher Education for Inclusive Education University of Aberdeen, 18-20 October 2009.

Saloviita, T. (2005): Erityisopetus opettajankoulutuksen sisältöalueena. [Special education as a content area of teacher education]. In Jakku-Sihvonen, R. (ed.) Uudenlaisia maistereita. Keuruu: Otava 339-351.

Tübele, S. (2008): The study course 'Introduction to Special Needs Education' - a step towards teacher education for inclusive education at the University of Latvia. Paper presented at: Cross-National Invitational Symposium on Teacher Education for Inclusion University of Aberdeen, 2-4 November 2008.

United Nations (2006): Convention on the Rights of People with Disabilities. New York, United Nations.

UNESCO (2000): World Education Forum. The Dakar framework for Action: Education for All - Meeting our Collective Commitments. Paris, UNESCO.

Vandeputte, I., Vanacker, S., Vanbuynder, G. (2007): Vorming van de basiscompetenties van leranen in de initele lerarenpleiding voor het werken in een inclusieve setting via actieonderzoeck. [Composing the basic teacher competences in initial teacher education for inclusive settings through action-research] Katholieke Hogeschool SintLieven, Campus Sint-Niklaas, 2007, www.kahosl.be

Young, K. (2008): I don't think I'm the right person for that: Theoretical and institutional questions about a combined credential program. Disability Studies Quarterly 28 (4), 1-16. Available on line at: http://dsq-dsd.org/ Last accessed 19/11/2009.

A cikket fordította: Szegedi Eszter, Szerkesztette, ellenőrizte: Kimmel Magdolna 